\title{
NSF aims to inject more maths into biology
}

\section{Rex Dalton, San Diego}

In a bid to bring more direction to a somewhat chaotic field, the US National Science Foundation (NSF) has launched an ambitious plan to increase biologists' use of mathematical and statistical techniques.

The agency wants researchers to build these techniques into their grant proposals. The scheme's initial budget will be at least $\$ 3$ million, say officials, and future budget requests could boost agency-wide support to $\$ 100$ million.

It is hoped that the initiative will provide tools for analysing the large data sets that will come from research programmes such as the planned National Ecological Observatory Network, a system of long-term monitoring facilities. The eventual goal is to find definitive answers to questions on population dynamics, dispersal of species over large areas, and the impact of ecological variables.

NSF officials say the fund will initially target neurobiology, animal behaviour, ecology and evolutionary physiology. New numerical techniques could be applied at every level from genes to ecosystems.

The NSF has sent out notices about the initiative, known as Quantitative Environmental and Integrative Biology. The agency's biological sciences directorate and its mathematics and physical-sciences directorate will use their core programmes to encourage the funding of research incorporating the new approach.

The notice says that the time is ripe to use existing mathematical tools and develop new approaches to speed up progress towards understanding and predicting environmental and integrative biology.

Principal investigators are being encouraged to train undergraduates and graduates in the new techniques, with a view to them becoming involved in the research. NSF officials see this as a way to create a muchneeded generation of scientists skilled in both biology and mathematics.

Earlier this month, at an NSF-sponsored workshop at the University of California at San Diego's Supercomputer Center, mathematicians, statisticians and biologists came together to give the agency guidance on the types of project it should fund.

According to Margaret Palmer, director of the NSF's division of environmental biology and an aquatic ecologist at the University of Maryland, the consensus was that the initial targets should be population genetics, ecological system restoration, and animal physiology and behaviour.

People were excited about the potential for progress at the interface of environmental biology and mathematics, says Alan Hastings, an ecological mathematician at

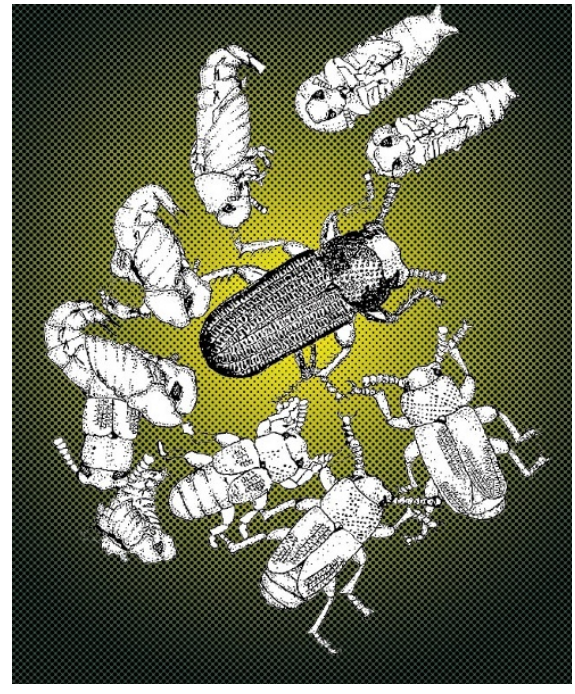

Adding up: maths has been used successfully to predict changes in flour-beetle populations.

the University of California at Davis, who organized the workshop. The most interest, Hastings said, surrounded the issues of randomness and variability.

Scientists have had some success at developing models to analyse population data, for example, with the flour beetle, voles and Dungeness crabs, predicting population parameters and working out what determines species populations.

But difficult challenges remain, particularly in studying species spread over large areas. Many serious ecological questions involve space, such as the spread of invading species and genetically modified traits through native populations, says Tony Ives, a University of Wisconsin zoologist who participated in the workshop.
For wide-ranging populations, data at any one location are likely to be sparse, leading to statistical problems with characterizing populations. One attempt to address this involved a team of mathematicians and ecologists who worked with laboratory populations of the flour beetle Tribolium castaneum.

This produced a seminal paper (see Nature $375,227-230$; 1995) showing how a mathematical model could be used to predict changes in a species where cannibalism leads to wildly differing population growth rates.

At the NSF workshop, members of the team - Brian Dennis of the University of Idaho, Robert Desharnais of California State University at Los Angeles and Shandelle Henson of the College of William and Mary in Williamsburg, Virginia - explained how their techniques can be applied to species in the wild, translating biology into mathematical language.

http://caldera.calstatela.edu/nonlin

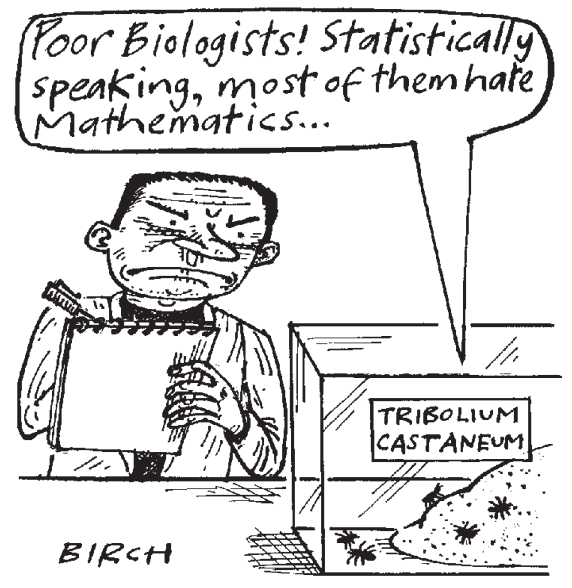

\section{France backs IT and life sciences}

\section{Declan Butler, Paris}

France's spending on civil research and development will place a greater emphasis on information technology and the life sciences next year, science minister RogerGérard Schwarzenberg revealed last week.

Schwarzenberg also launched a plan to recruit young scientists which will be used to direct strategic goals towards these two fields and reduce the heavy burden of salaries on research agencies' budgets.

The FFr55.8 billion (US $\$ 7.5$ billion) budget for 2001 is a $2.2 \%$ increase on this year. But overall, science came only seventh in additional spending - the ministry of environment, for example, got an $8 \%$ boost.

There will be 265 new full-time posts for researchers and technicians in public research agencies, compared with 150 in 1999 and just 18 last year. This is partly because half of France's current researchers will retire between 2004 and 2010.

Of the new posts, 116 will go to the National Institute for Research in Computing Science and Control (INRIA). Many of the 70 jobs at the Centre National de la Recherche Scientifique (CNRS) will go to a department of information technology, which is expected to be formally created alongside the seven existing CNRS departments this week.

INRIA's $12.7 \%$ rise tops the budget handouts to the national agencies. The national biomedical agency INSERM got a $4.2 \%$ increase and CNRS got $0.9 \%$.

Schwarzenberg said that $25 \%$ more public researchers would come into 


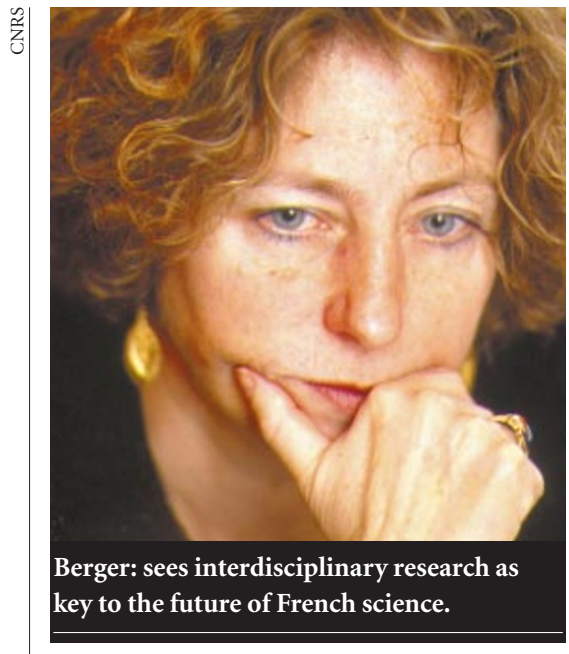

information technology over the next five years. Given that 74 of the new jobs will go to INSERM, and that many of the noncomputing posts at the CNRS will go to the life sciences, the harvest for other disciplines has been meagre. Jacques Fossey, secretary-general of the main researchers' trade union, the National Union of Scientific Researchers (SNCS), is among those critical of this imbalance.

But Geneviève Berger, the new director-general of the CNRS, says that she will not neglect physics and chemistry. Rather, in a bid to boost interdisciplinarity, she wants to see more researchers in these areas applying for jobs in life-science research.

Berger is also planning a bioinformatics programme to link the life sciences with the proposed information technology department. And she wants to introduce within six months a new 'matrix' model for research at the CNRS, with projects cutting across disciplinary boundaries.

Berger sees the wave of retirements as a golden opportunity to make the management of research more flexible. At present, over three-quarters of the CNRS budget goes on salaries, leaving little for equipment and supplies. She would like to see this cut to $60 \%$.

Berger does not intend to challenge researchers' status as civil servants. But she wants fewer full-time researchers and more temporary posts, to allow more foreign researchers to work at the CNRS. A system of three-year postdoctoral fellowships, renewable once, is also under consideration.

Having studied the budget figures, the SNCS claims that, despite the government's emphasis on job creation, it intends to increase spending on research infrastructure by cutting the wage bill. Describing this as "scandalous", the union is urging the National Assembly to amend the budget bill when it comes up for approval later in the autumn.

\section{Disagreements derail US bill to double research funding...}

Colin Macilwain, Washington

The hopes of US scientific societies that Congress would pass a bill to double research spending in each of the major nonmilitary research agencies collapsed last week, when the chairs of the relevant committees in the House and Senate failed to reach agreement on the bill's contents.

After four months of negotiations between the staff of James Sensenbrenner (Republican, Wisconsin), chair of the science committee in the House of Representatives, and Senator Bill Frist (Republican, Tennessee), Sensenbrenner refused to support Frist's proposal in the House - almost certainly ending its prospects of passage this year.

Sensenbrenner wants a bill supporting increased research funding in information technology, whereas Frist backs a much broader bill supporting all types of research.

In a detailed letter sent to Frist on 19 September, Sensenbrenner said that Frist's proposals "would provide little support for scientific research funding while undermining the science committee's ability to operate as an effective legislative entity".

If passed, Frist's bill would not guarantee a doubling of each agency's budget, but it would set an overall target for expenditure over several years. Sponsors hope this would influence the appropriations committees when they allocate the agencies' annual budgets.

Sensenbrenner is thought to oppose the bill mainly on the grounds of cost. But his letter argues that it would also reduce the prospects of Congress considering detailed legislation for science agencies — such as the
NASA reauthorization bill passed this year - and would further reduce his committee's influence on the appropriations process.

Two days after Sensenbrenner's letter, the Senate unanimously passed Frist's bill, the Federal Research Investment Act. But without Sensenbrenner's support, it has little chance of being considered by the House during this session.

In an angry reply to Sensenbrenner, Frist indicated that the science committee chairman had failed to live up to promises made in their negotiations. "You simply are holding the Federal Research Investment Act up to a different standard than you do your own committee bills," he wrote. He added that "anything less" than Sensenbrenner's support for the act "would be in direct contradiction to our previous negotiations".

Scientific societies, including the American Physical Society and the American Chemical Society, have been trying to build support for the measure for over three years (see Nature 394, 5; 1998). They believe the bill will ensure research agencies supporting the physical sciences - such as the Department of Energy - will not be left behind as Congress backs the rapid expansion of life sciences at the National Institutes of Health.

Some science lobbyists have said that the bill should be abandoned if it fails in the current session. But according to staff, Frist will pursue it in the new Congress next year. What ever happens in November's election, Sensenbrenner is not expected to chair the science committee. His departure will remove the largest single obstacle to the bill's passage.

\section{... as physical sciences plan lobbying body}

Scientific societies and research foundations plan to set up a lobbying body in Washington to boost public support for investment in the physical sciences, mathematics and engineering.

Impressed by the success of Research!America, a society that lobbies for the life sciences, various scientific bodies have provided around $\$ 100,000$ with which to prepare a business plan. The interim director of the body is to be Merrilea Mayo, a materials scientist from Pennsylvania State University.

The attempt to establish the as-yet-unnamed outfit has been spearheaded by Mary Good, a professor at the University of Arkansas and former undersecretary of technology at the commerce department in President Bill Clinton's administration. The physical sciences, says Good, "need a continuous presence" in

Washington. "We need to have the community speak with one voice, instead of 30 or 40 ."

Those involved in the effort say the precise role of the new body has yet to be defined, and that its success will depend on how much support it can attract

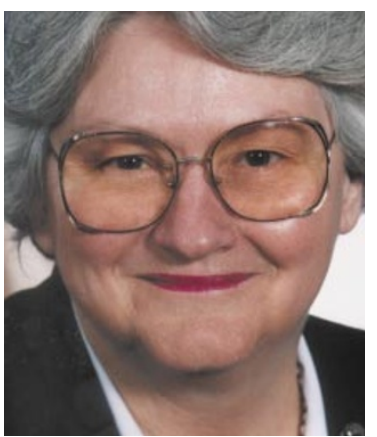

Good: believes the physical sciences need a single voice.

from sectors of industry that want the federal government to invest more in the physical sciences. C.M. 